JURNAL ILMIAH KEBIDANAN IMELDA

Vol.7, No.1, Maret 2021, pp. 42-46

ISSN: 2597-7180 (Online), 2442-8116 (Print)

http://jurnal.uimedan.ac.id/index.php/JURNALKEBIDANAN

\title{
HUBUNGAN EKSTRAK DAUN KENTANG MANIS DENGAN PRODUKSI ASI DI KLINIK SITI HAJAR MEDAN
}

\author{
Debora Paninsari ${ }^{1}$, Clarita Angelina ${ }^{2}$, Viona Rozalina ${ }^{3}$, Patimah ${ }^{4}$ \\ Universitas Prima Indonesia, Indonesia
}

\begin{tabular}{l}
\hline Article Info \\
\hline Article history: \\
Received Feb 26, 2021 \\
Revised Mar 04, 2021 \\
Accepted Mar 13, 2021 \\
\hline
\end{tabular}

\section{Keywords:}

Breas Milk

Postpartum Mothers

Sweet Potato Leaves

\begin{abstract}
Breast milk is an emulsion of fat contained in a solution of protein, lactose, and organic salts which will be secreted by both breast glands as the main source of food for the baby. Increasing milk is very necessary for mothers by consuming foods such as: sweet potato leaves, the content contained in sweet potato leaves is low in fat and cholesterol etc. Sweet potato leaves can increase milk production because sweet potato leaves contain lactagogum. The purpose of this study was to determine whether or not there was a relationship between consuming sweet potato leaf extract and an increase in breast milk production at the SitiHajar Medan clinic, Marelan. Methods: pre $=$ post test. This study measured the mother's milk before and after being given sweet potato leaves from January 2021 to February 2021. Samples were taken at the Siti Hajar Medan clinic with a total of 50 samples, with the inclusive criteria being mothers who gave birth normally and healthy babies. Univariate analysis was carried out to describe the variables with the results of $46 \%$ as many as 23 (people) intervention of mother's milk production increased after consuming sweet potato leaves compared to before consuming with a result of $4 \%$ as many as 2 (people). Bivariate analyst to determine the relationship between independent and variables using the Wilcoxon test, based on the results of the Wilcoxon test, the p-value is 0.000 $(<0.05)$. And In conclusion, there is a significant relationship between consuming sweet potato leaves and increasing breast milk production.
\end{abstract}

This is an open access article under the CC BY-SAlicense.

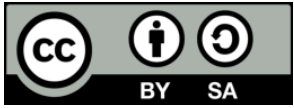

\section{Corresponding Author:}

Debora Paninsari,

S1 Kebidanan,

Universitas Prima Indonesia,

Jl. Danau Singkarak, Gg. Madrasah SeiAgul, Kec.Medan Barat, Medan - Sumatera Utara.

Email: claritaangelian28@gmail.com

\section{INTRODUCTION}

ASI (Air Susu Ibu) adalah suatu emulsi lemak dalam larutan protein, lactose dari garam organic yang nantinnya akan di sekresi oleh kedua belah kelenjar payudara ibu, sebagai makanan utama bagi bayi. Dari stadium laktasi, komposisi yang ada didalam ASI tidak akan sama dari hari ke hari (Proverawati dan Rahmawati, 2017). Masalah ketika ibu tidak ingin menyusi bayinya banyak di sebabkan karena ASI yang keluar sedikit ibu takut payudara akan kendur disebabkan oleh bertambahnya usia dan kehamilan, Puting terbenam tidak berarti tidak dapat menyusui bayi karena yang menyusui itu pada payudara bukan pada putting, (WHO, 2017).

Metode yang dapat digunakan untuk meningkatkan volume ASI (Lactogogue) yaitu dengan meminum atau makanan, ramuan yang terbukti dapat meningkatkan volume ASI, dengan konsumsi daun kentang manis (Ritawati, 2017). Daun kentang manis memiliki kandungan yang berupa lemak dan kolesterol 
yang sangat rendah. Dan juga dapat menaikkan volume ASI karena didalam daun kentang manis terdapat zat laktagogum yang dapat menaikkan volume air susu ibu sehingga dapat memenuhi kecukupan ASI bagi bayi (Utami Roesli, 2016).

Daun kentang manis (Ipomoea batatas), merupakan daun yang memiliki berbagai manfaat seperti, dapat mengobati peradangan, meningkatkan kesehatan mata, menaikkan volume ASI ibu, dapat mengobati kolesterol, dll. Karena di dalam daun ini terkadung berbagai macam sumber energi bagi tubuh seperti, vitamin c, vitamin B6, kalsium, magnesium, vitamin A dan banyak lagi kandungan lain nya, dan salah satunya yang dapat menaikkan volume ASI ialah zat laktagogum yang terdapat di dalam daun ini, sehingga nantinya gizi bayi akan tercukupi dengan naiknya volume air susu ibu (Bibi dkk, 2016).

Menurut Data yang di dapat dari Kesehatan dunia (WHO, 2016) masih menunjukkan bahwa ratarata angka pemberian ASI Eksklusif sejumlah besar perempuan (96\%) tidak menyusui anak mereka di kehidupan mereka, dan hanya $42 \%$ dari bayi berusia 6 bulan yang mendapatkan ASI Eksklusif. (Pramita, E, 2017). Berdasarkan survey di Indonesia, 73\% ibu berhenti memberikan ASI karena kurangnya produksi ASI. Serta kurangnya usaha dan upaya dalam meningkatkan produksi ASI dengan memakan ramuan atau makanan yang bisa meningkatan suplai produksi ASI. Jika tidak akan mempengaruhi kinerja hormone oksitosin dan prolaktin yang membuat produksi ASI semakin menurun, yang dapat menyebabkan pembendungan ASI dan mastatis (Dokko, dkk, 2019).

Karena masih tinggi nya persentase ibu yang tidak memberikan ASI Eksklusif kepada bayinya, di karenakan kurangnya produksi ASI, serta memiliki kendala lainya pada proses pengeluaran ASI yang tidak lancar, banyak ibu yang lebih memilih menggunakan susu formula untuk bayinya. Maka peneliti tertarik untuk melakukan penelitian dengan menggunakan strategi dengan memanfaatkan menu makanan, tentang hubungan ekstrak daun kentang manis dengan produksi ASI, karena seperti yang sudah diketahui sebelumnya bahwa di dalam daun kentang manis memiliki zat laktagogum yang terkadung didalam nya. Tujuan dari penelitian ini untuk melihat apakah ada hubungannya dengan mengkonsumsi daun kentang manis dengan meningkatnya Volume ASI dan secara otomatis akan meningkatkan kecukupan gizi dan nutrisi bagi bayi.

\section{RESEARCH METHOD}

Penelitian yang digunakan adalah penelitian Explanatory Research, menggunakan penelitian kuantitatif dan fase kualitatif dengan mengadopsi jenis penelitian merekrut 50 partisipan. Sedangkan fase penelitian kualitatif pedoman wawancara 10 partisipan (Arikunto, 2015). Tujuan dari penelitian ini ialah untuk mengetahui adakah pengaruh kenaikkan volume air susu jika mengkonsumsi daun kentang manis. Penelitian kuantitatif menggunakan desain cross sectional dengan teknik proportional random sampling, untuk menentukan besar sampel menggunakan rumus: $\mathrm{n}=\mathrm{X} / \mathrm{N}$ x Ni. Pencatatan dan wawancara dilakukan secara sadar, terarah dan senantiasa bertujuan memperoleh informasi yang diperlukan. Data yang dikumpulkan dalam observasi berasal dari pengamatan tingkah laku responden dan pembicaraan yang ringan serta santai. Populasi dalam penelitian ini berjumlah 100 orang ibu nifas. Dengan jumlah sampel 50 orang. Penelitian ini dilakukan karena masih banyak ibu yang tidak memberikan ASI Eksklusif pada bayinya dikarenakan ASI yang keluar sedikit.

\section{RESULTS AND ANALYSIS}

\subsection{Hasil}

Adapun hasil yang didapat dari penelitian ini adalah sebagai berikut:

Tabel 1. Karakteristik Distribusi Responden Menurut Umur dan Pendidikan Di Klinik Siti Hajar Medan

\begin{tabular}{|c|c|c|}
\hline Variabel & Freukensi & Presentase $(\%)$ \\
\hline \multicolumn{3}{|l|}{ Umur } \\
\hline $1 \quad 21-25$ & 12 & $24 \%$ \\
\hline $226-29$ & 15 & $30 \%$ \\
\hline $3 \quad 30-33$ & 23 & $46 \%$ \\
\hline Jumlah & 50 & $100 \%$ \\
\hline \multicolumn{3}{|l|}{ Pendidikan } \\
\hline 1 SMP & 7 & $14 \%$ \\
\hline 2 SMA & 41 & $82 \%$ \\
\hline $3 \mathrm{~S} 1$ & 2 & $4 \%$ \\
\hline Jumlah & 50 & $100 \%$ \\
\hline
\end{tabular}

Berdasarkan tabel 1 dari data Karakteristik Umur diperoleh usia 21-25 sebanyak 12 orang kemudian usia 26-29 sebanyak 15 orang dan usia 30-33 sebanyak 23 orang. Berdasarkan karakteristik pendidikan SMP berjumlah 7 orang kemudian SMA berjumlah 41 orang dan S1 berjumlah 2 orang. 
Tabel 2. Pengeluaran ASI Sebelum Diberikan Ekstrak Daun Kentang Manis

\begin{tabular}{cccc}
\hline No & Variabel & Frekuensi & Presentase \% \\
\hline 1 & $300-400$ kurang & 37 & $74 \%$ \\
\hline 2 & $401-500$ cukup & 11 & $22 \%$ \\
\hline 3 & $501-750$ Baik & 2 & $4 \%$ \\
\hline & Total & $\mathbf{5 0}$ & $\mathbf{1 0 0 \%}$ \\
\hline
\end{tabular}

Berdasarkan tabel 2 dari data Pengeluaran ASI Sebelum dilakukan pemberian Ekstrak Daun Kentang Manisdiperoleh data300-400 (kurang) sebanyak 37 orang.

Tabel 3. Pengeluaran ASI Sesudah Diberikan Ekstrak Daun Kentang Manis

\begin{tabular}{cccc}
\hline No & Variabel & Frekuensi & Presentase \% \\
\hline 1 & $300-400$ kurang & 12 & $24 \%$ \\
\hline 2 & $401-500$ cukup & 15 & $30 \%$ \\
\hline 3 & $501-750$ Baik & 23 & $46 \%$ \\
\hline & Total & $\mathbf{5 0}$ & $\mathbf{1 0 0 \%}$ \\
\hline
\end{tabular}

Berdasarkan tabel 3 dari data Pengeluaran ASI sesudah dilakukan pemberian Ekstrak Daun Kentang Manis diperoleh data 501-750 (baik) sebanyak 23 orang.

Tabel 4. Perbandingan Uji Wilcoxon Signed Rank Sebelum dan Sesudah Diberikan Pemberian Ekstrak Daun Kentang Manis Di Klinik Siti Hajar Medan

\begin{tabular}{|c|c|c|c|c|}
\hline Variabel & Mean Rank & p value & $Z$ & Keputusan \\
\hline Sebelum & 18,19 & 0.000 & \multirow{2}{*}{$-5,159^{b}$} & $\mathrm{H}_{\mathrm{o}}$ ditolak \\
\hline Sesusah & 11,50 & 0.000 & & $\mathrm{H}_{\mathrm{o}}$ ditolak \\
\hline
\end{tabular}

Berdasarkan tabel 4 hasil dari uji Wilcoxon Signed Rank Test pre test dan post test didapatkan hasil dari dengan pemberian Ekstrak Daun Kentang Manis nilai Z senilai -5,159 dengan nilai p-value sebesar 0,000. Dari nilai uji $p$-value yang artinya lebih kecil dari $0,05(0,000<0,05)$. Sehingga dapat kita artikan bahwa Ho ditolak, terdapat perbedaanantara sebelum dan sesudah dilakukan pemberian Ekstrak Daun Kentang Manis dengan produksi ASI pretest dan posttest.

\subsection{Pembahasan}

Pembahasan dalam hal ini menjelaskan hasil penelitian mengenai Hubungan Ekstrak daun kentang manis dengan produksi ASI di Klinik Siti Hajar Medan Tahun 2021 dengan 50 responden sebagai sampel. Frekuensi responden menurut umur, pendidikan menyatakan bahwa umur diperoleh usia 21-25 sebanyak 12 orang kemudian usia 26-29 sebanyak 15 orang dan usia 30-33 sebanyak 23 orang. Berdasarkan Karakteristik Pendidikan SMP berjumlah 7 orang kemudian SMA berjumlah 41 orang dan S1 berjumlah 2 orang.

Hal ini menunjukkan terjadinya selama 5 hari dalam satu minggu, dengan dosis 3 kali sehari 2 kapsul (setara dengan 100 gram daun kentang manis segar). Berdasarkan hasil penelitian yang dilakukan (Weni Tri Purnani, 2017), kecukupan ASI bayi didapatkan dengan mengkonsumsi rebusan daun kentang manis secara rutin yaitu setiap 2x/hari selama 7 hari, dengan takaran 100 gram daun kentang manis setiap harinya selama proses menyusui akan didapatkan hasil yang maksimal, dengan itu maka kecukupan ASI akan memenuhi nutrisi yang diperlukan bayi akan tercukupi dengan baik.

Menurut hasil penelitian yang dilakukan (Endang Suwanti dkk, 2016), peningkatan produksi ASI melalui konsumsi daun kentang manis, hal ini karena dalam daun tersebut ada zat-zat laktagogum yang bisa meningkatkan produksi ASI, selain itu di dalam daun ini juga ada kandungan karoteniid dan zat besi dengan p-value 0,000. Dengan mengkonsumsi daun kentang manis akan meningkatkan volume air susu ibu dengan secara otomatis kecukupan ASI bagi bayi akan terpenuhi begitupun dengan gizi bayi, dengan adanya penelitian tentang daun kentang manis ini di harapkan akan menambah pengetahuan ibu tentang cara yang dapat digunakan ibu untuk menambah volume air susu agar gizi bayi tercukupi dan bayi sehat.

Dari hasil penelitian ini yang dimana populasi yang digunakan oleh peneliti adalah ibu menyusui, di Klinik Siti Hajar Medan, di dapatkan hasil yang efektif karena daun kentang manis berpengaruh terhadap meningkatkan volume ASI, yang dimana sebelum melakukan pemberian daun kentang manis di lakukan pengukuran ASI dan dilakukan pengukuran ASI kembali setelah ibu mengkonsumsi daun kentang manis, hasil penelitian ini juga sesuai dengan teori yang dimana daun kentang manis mengandung provitamin A dan protein yang tinggi, dengan berarti semakin sering mengkonsumsi makanan yang mengandung Vit A seperti: daun katuk, kangkung, sawi, bayam, daun kentang manis, daun singkong, maka volume ASI akan meningkan dan dapat memenuhi kecukupan ASI bagi bayi ibu. Selain itu daun kentang manis juga mudah didapatkan dan harga nya juga lebih ekonomis sehingga ibu dapat dengan mudah untuk mengolah dan memanfaaatkannya untuk meningkatkan volume ASI dan mengsukseskan program ASI Ekslusif, karena ASI 
adalah asupan nutrisi yang aman dan lengkap yang sangat di butuhkan untuk 6 bulan pertama kehidupan bayi.

\section{CONCLUSION}

Berdasarkan hasil penelitian yang dilakukan peneliti tentang "hubungan ekstrak daun kentang manis dengan produksi ASI di klinik siti hajar medan tahun 2021" maka dapat disimpulkan sebagai berikut:

1. Pengeluaran ASI Sebelum dilakukan pemberian Ekstrak Daun Kentang Manis diperoleh data 300-400 (kurang) sebanyak 37 orang, 401-500 (cukup) sebanyak 11 orang dan 501-750 (baik) sebanyak 2 orang

2. Pengeluaran ASI Sesudah dilakukan pemberian Ekstrak Daun Kentang Manis diperoleh data 300-400 (kurang) sebanyak 12 orang, 401-500 (cukup) sebanyak 15 orang dan 501-750 (baik) sebanyak 23 orang

3. Hasil dari uji Wilcoxon Signed Rank Test pre test dan post test didapatkan hasil dari dengan pemberian Ekstrak Daun Kentang Manis nilai Z senilai -5,159 dengan nilai $p$-value sebesar 0,000. Dari nilai uji $p$ value yang artinya lebih kecil dari $0,05(0,000<0,05)$. Sehingga dapat kita artikan bahwa $\mathrm{H}_{0}$ ditolak, terdapat perbedaan antara sebelum dan sesudah dilakukan pemberian Ekstrak Daun Kentang Manis dengan produksi ASI pretest dan posttest. Dan berdasarkan teori dan hasil uji di dapatkan bahwa ada hubungan antara mengkonsumsi daun kentang manis dengan meningkatkan volume air susu ibu, Penelitian ini adalah salah satu contoh menu makanan yang dapat di gunakan bagi ibu meningkatkan atau menambah volume ASI.

\section{REFERENCES}

[1] Arikunto. (2015). Prosedur Penelitian Suatu Pendekatan Pratik. Jakarta: Rineka Cipta.

[2] Bibi Ahmad Chahyanto dan Katrin Roosita. 2015. Hubungan antara asupan vitamin A dengan produksi ASI pada ibu nifas.

[3] Balitbangkes. 2019. Laporan Nasional RISKESDAS 2018.

[4] Doko, T. M., Aristiati, K., \& Hadisaputro, S. 2019. Pengaruh Pijat Oksitosin oleh Suami terhadap Peningkatan Produksi Asi pada Ibu Nifas. Jurnal Keperawatan Silampari, 2(2), 66-86. https://doi.org/10.31539/jks.v2i2.5 29 Garovic, V. D.

[5] Dinas Kesehatan Provinsi Sumatera Utara. 2016. Profil Kesehatan Kota Medan 2016. 46-7.

[6] Soetjitiningsih. 2016. Seri Gizi Klinik ASI Petunjuk Untuk Tenaga Kesehatan. Jakarta: EGC.

[7] Saifuddin, Azwar. 2015. Metode Penelitian. Yogyakarta: Pustaka Pelajar Basd.

[8] Suprati ML. 2017. Tepung Ubi Jalar Pembuatan Dan Pemanfaatannya. Yogyakarta: Kanisus.

[9] Soekijo, Notoatmojo. 2017. Buku Metodologi Penelitian Kesehatan. Jakarta: Renika Cipta.

[10] Proverawati, A. 2017. Kapita Selekta ASI Dan Menyusui. Yogyakarta: Nuha Medika.

[11] Pollard, M. 201). ASI Asuhan Berbasis Bukti. Jakarta: EGC.

[12] Pramita, E. 2017. Pekan ASI Sedunia 2017: Mari Mendukung Keberhasilan Ibu Menyusui. Jakarta: Majalah Kartini.

[13] Ritawati. 2017. Jurnal Penelitian Sukses ASI Eksklusif Dengan Daun Ubi Jalar Pada Ibu Nifas. (diakses tanggal 13 februari 2016)

[14] Rahmawati Anita. 2017. Analisis faktor yang mempengaruhi Produksi Air Susu Ibu (ASI) Pada Ibu Menyusui Yang Berkerja. Jurnal Nersdan Kebidanan 4(2): hal 134-140.

[15] WHO. 2017. Guidelines on Optimal feeding of low birth weight infants in lowand middle-income countries. WHO Library Cataloguing-in-Publication Data.

\section{BIOGRAPHIES OF AUTHORS}

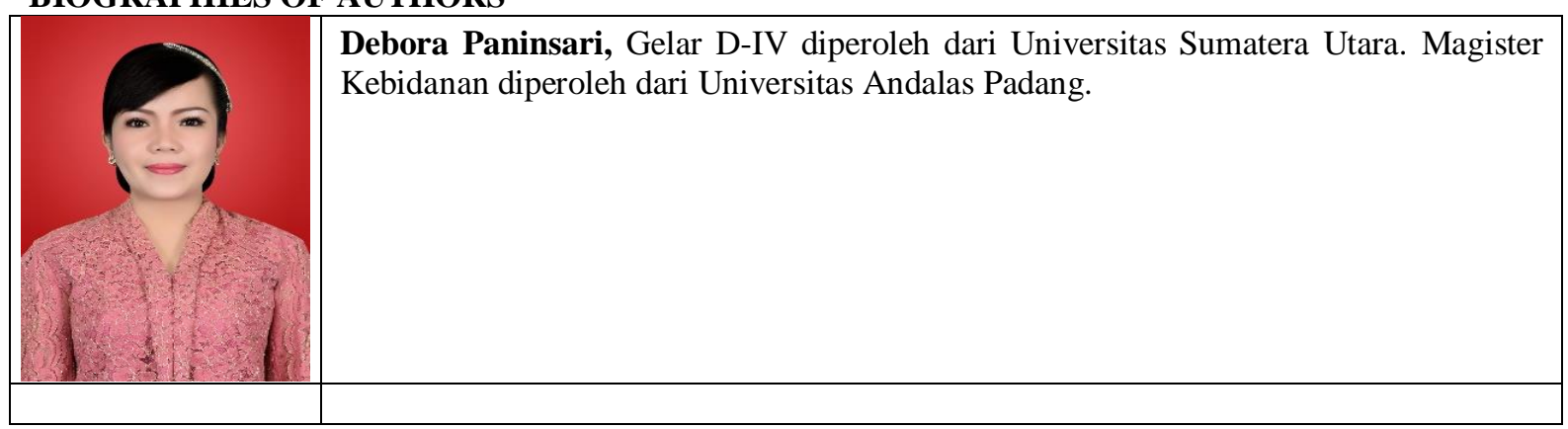




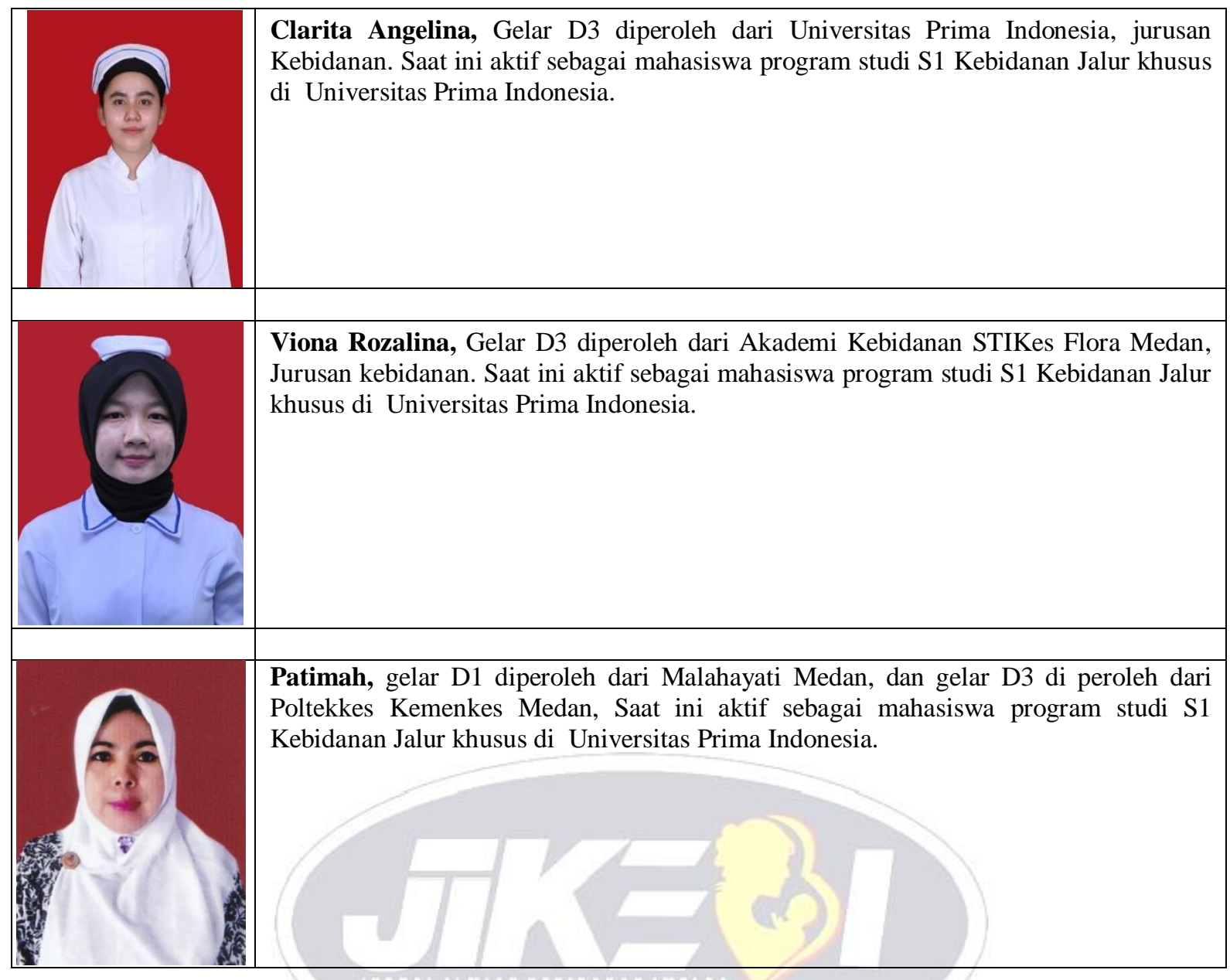

